\title{
PERFORMANCE ANALYSIS OF PARTIALLY COVERED PHOTOVOLTAIC THERMAL (PVT) WATER COLLECTOR
}

\author{
Pratish Rawat $^{1}$, K.Sudhakar ${ }^{2}$ \\ ${ }^{1}$ Assistant Professor, Mechanical Department, Poornima University, Jaipur, Rajasthan, India \\ ${ }^{2}$ Assistant Professor, Energy Centre, Maulana Azad National Institute of Technology Bhopal, India \\ Email:pratishrawat@gmail.com (Corresponding Author)
}

\begin{abstract}
In this paper the photovoltaic thermal (PVT) water collector partially covered by glass and its energy and exergy analysis were carried out. The various parameters were computed such as thermal efficiency, electrical efficiency, exergy efficiency etc on daily basis for Meteorological conditions of Bhopal, India in the month of May. It is found that the maximum temperature of hot water from PVT system on particular day was found to be 47.5 OC with mass flow rate of $0.0025 \mathrm{~kg} / \mathrm{sec}$. The thermal efficiency, electrical efficiency and energy saving efficiency of the system were found to be exceeding $67 \%, 9 \%$ and $67 \%$ respectively. The use of PVT system, not only reduce the electrical load from conventional energy sources but also produces two form of energy from single system i.e. electricity and thermal.
\end{abstract}

Key Words: Energy, Exergy, Solar PVT Collector, PVT System, Solar Energy, Performance Analysis

\section{INTRODUCTION}

A huge amount of research on solar PV-thermal hybrid collectors has been carried out over the past three decades. A photovoltaic-thermal (PVT) system is developed by combining solar photovoltaic and solar thermal system. The PVT system is an integrated system which can produce both electricity and heat at the same time. A hybrid photovoltaic thermal (PVT) solar energy system consists of a PV panel at the back of which a heat exchanger is attached. The PVT system refers to a system that extracts heat from the panel by using heat transfer fluid, usually water or air and sometimes both. There are many reasons which motivate the researchers to develop various models and designs of the PVT system. One of the main reasons is that PVT system can provide higher efficiency than individual PV and thermal collector system. The integration of two systems to one not only increases the efficiency of overall system but also reduces the payback period. Solar PVT collectors can be classified as:

1. PVT liquid collector

2. PVT air collector

3. PVT Liquid and air collector

4. PVT concentrator (CPVT)

There are various approaches in PVT system designing. The solar PVT design parameters are based on type of working fluid, thermal and electrical efficiency, solar radiation and working temperature. The solar PVT water collector system consists of conductive-metal pipes or plates attached to the back of a PV module which acts as an absorber, absorbs heat from back of module and transfer it to circulating fluid. In this arrangement, water is flowed through these pipes with the help of pump. In solar PV system, high incident solar radiation on solar PV panel give high electrical output but at the same time it also increase the temperature of the solar cells and that results in reduction in the efficiency of the panel. At standard temperature and pressure (STP) conditions and depending on type of material of solar cell, the electrical conversion efficiency of commercially available solar panel is in the range of $6-15 \%$. It has been found that with every increase of $1{ }^{0} \mathrm{C}$ in temperature of solar $\mathrm{PV}$ panel, there is reduction of the efficiency by $0.5 \%$.

\subsection{Application of solar PVT system}

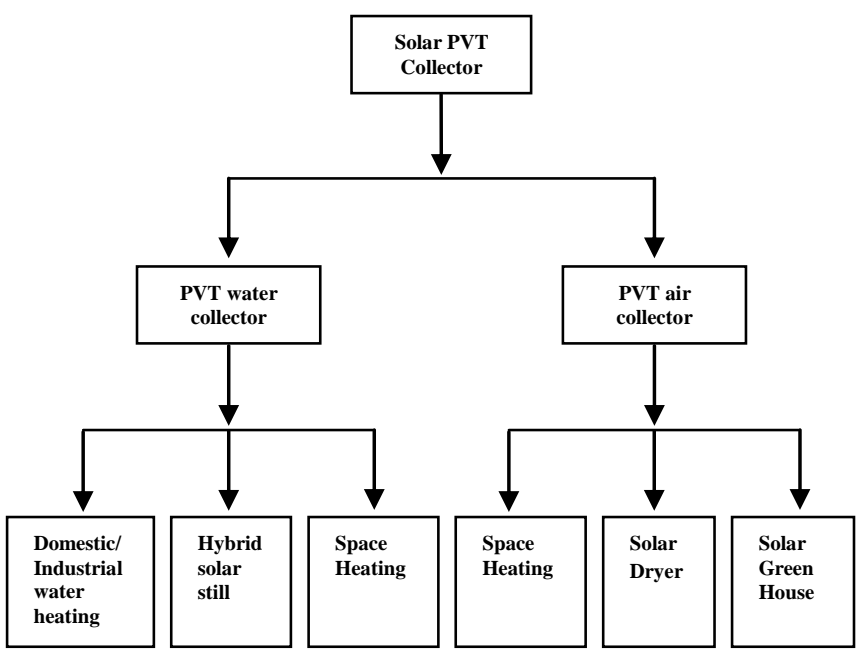

\subsection{Advantages of PV/T system}

1. Maximizes yield from sun's energy where roof space is restricted

2. Cooling circuit improves efficiency of solar PV cells

3. Cost of manufacturing and installation reduced

4. Low maintenance 


\section{METHODOLOGY}

\subsection{Experiment Methodology}

In the construction of solar PV/T system $37 \mathrm{~W}$ polycrystalline silicon solar panel is used. A combination of copper sheet and tubes is attached at back side of panel which act as absorber. Water is circulated as coolant in the pipes with the help of pump. A transparent glass cover is used which partially cover the solar PV panel. The experiments were carried out at M.A.N.I.T. Bhopal (latitude of $23.16^{\circ} \mathrm{N}$; longitude of $77.24^{\circ} \mathrm{E}$ ) India. Various parameters are measured during the experiment such as Solar intensity, wind velocity, ambient temperatures, relative humidity, open circuit voltage, short circuit current, maximum power, front side and back side temperature of module, fill factor, etc. The parameters were measured in every one hour from 10.00 a.m. in the morning to 5.00 p.m. in the evening.

Table 2.1: Meteorological Conditions

\begin{tabular}{|l|l|}
\hline Location & Bhopal, Madhya Pradesh, India \\
\hline $\begin{array}{l}\text { Meteorological } \\
\text { Conditions }\end{array}$ & $\begin{array}{l}\text { Latitude of } 23.16^{\circ} \mathrm{N} ; \\
\text { Longitude of } 77.24^{\circ} \mathrm{E}\end{array}$ \\
\hline Month & May 2014 \\
\hline Time & 10.00 a.m. to 5.00 p.m. \\
\hline
\end{tabular}

Table 2.2: Technical specification of PV/T system

\begin{tabular}{|c|c|c|}
\hline 1 & $\begin{array}{l}\text { Solar PV module } \\
\text { type }\end{array}$ & Polycrystalline \\
\hline 2 & Maximum power & $37 \mathrm{~W}$ \\
\hline 3 & $\begin{array}{l}\text { Voltage at max. } \\
\text { power }\left(\mathrm{V}_{\mathrm{mp}}\right)\end{array}$ & $17 \mathrm{~V}$ \\
\hline 4 & $\begin{array}{l}\text { Current at max. } \\
\text { power }\left(\mathrm{I}_{\mathrm{mp}}\right)\end{array}$ & $2.18 \mathrm{~A}$ \\
\hline 5 & $\begin{array}{l}\text { Short circuit } \\
\text { current }\left(\mathrm{I}_{\mathrm{sc}}\right)\end{array}$ & $2.30 \mathrm{~A}$ \\
\hline 6 & $\begin{array}{l}\text { Open Circuit } \\
\text { Voltage }\left(\mathrm{V}_{\mathrm{oc}}\right)\end{array}$ & $21 \mathrm{~V}$ \\
\hline 7 & Module area & 0.3216 sq. m. \\
\hline 8 & Absorber & $\begin{array}{l}\text { Copper sheet } 0.5 \mathrm{~mm} \text { thick and } \\
\text { copper tubes } 12 \mathrm{~mm} \text { diameter }\end{array}$ \\
\hline 9 & Fluid & Water \\
\hline 10 & $\begin{array}{l}\text { Submersible } \\
\text { Pump }\end{array}$ & $\begin{array}{l}\text { AC- } 220 \mathrm{~V}, 50 \mathrm{~Hz}, 18 \mathrm{~W}, \\
\text { Maximum lifting height }=1.65 \\
\mathrm{~m} .\end{array}$ \\
\hline
\end{tabular}

Table 2.3 Instruments Used in experiment

\begin{tabular}{|c|c|c|c|c|}
\hline S.No. & Instrument & Accuracy & Range & $\begin{array}{l}\text { Parameter } \\
\text { Measured }\end{array}$ \\
\hline 1 & $\begin{array}{l}\text { Solar } \\
\text { Module } \\
\text { Analyser }\end{array}$ & $+/-1 \%$ & $\begin{array}{l}0-10 \\
\mathrm{~V} \\
0.01- \\
10 \mathrm{~A}\end{array}$ & $\begin{array}{l}\mathrm{V}_{\mathrm{oc}}, \mathrm{I}_{\mathrm{sc}}, \mathrm{V}_{\mathrm{m}}, \\
\mathrm{I}_{\mathrm{m}}, \quad \mathrm{P}_{\mathrm{m}}, \\
\text { Efficiency, } \\
\text { Fill Factor }\end{array}$ \\
\hline 2 & $\begin{array}{l}\text { Solar Power } \\
\text { Meter }\end{array}$ & $+/-5 \%$ & $\begin{array}{l}0- \\
1999 \\
W / m^{2}\end{array}$ & $\begin{array}{l}\text { Solar } \\
\text { Irradiance }\end{array}$ \\
\hline 3 & $\begin{array}{l}\text { Humidity/ } \\
\text { Temperature } \\
\text { meter }\end{array}$ & $\begin{array}{l}0.1 \% \\
\text { R.H. } \\
+/-\quad 0.8 \\
{ }^{0} \mathrm{C}\end{array}$ & $\begin{array}{l}\text { R.H. } \\
-0- \\
80 \% \\
\& \quad 0- \\
50{ }^{0} \mathrm{C}\end{array}$ & $\begin{array}{l}\text { Ambient } \\
\text { Temperature, } \\
\text { Humidity }\end{array}$ \\
\hline 4 & $\begin{array}{l}\text { IR } \\
\text { Thermometer }\end{array}$ & $+/-2{ }^{\circ} \mathrm{C}$ & $\begin{array}{l}-18 \text { to } \\
400 \\
{ }^{\circ} \mathrm{C}\end{array}$ & $\begin{array}{l}\text { Surface } \\
\text { Temperature }\end{array}$ \\
\hline 5 & $\begin{array}{l}\text { Water proof } \\
\text { digital } \\
\text { thermometer }\end{array}$ & $+/-1{ }^{0} \mathrm{C}$ & $\begin{array}{l}-50 \text { to } \\
300 \\
0 \mathrm{C}\end{array}$ & $\begin{array}{l}\text { Inlet and } \\
\text { outlet water } \\
\text { temperature }\end{array}$ \\
\hline 6 & $\begin{array}{l}\text { Hot wire } \\
\text { Anemometer }\end{array}$ & $\begin{array}{ll}+/- & 0.1 \\
\mathrm{~m} / \mathrm{s} & \end{array}$ & $\begin{array}{l}0.2- \\
20 \\
\mathrm{~m} / \mathrm{s}\end{array}$ & $\begin{array}{l}\text { Wind } \\
\text { velocity }\end{array}$ \\
\hline
\end{tabular}

\subsection{Performance Evaluation}

Photo electric conversion efficiency is the ratio of useful electrical output of the system to the incident solar irradiation on the surface of collector within a given period. Photo Electric conversion efficiency

$\eta \mathrm{e}=\left(\mathrm{I}_{\mathrm{m}} \mathrm{V}_{\mathrm{m}}\right) /(\mathrm{GA})$

Thermal efficiency is the ratio of useful thermal energy output of the system to the incident solar irradiation on the surface of collector within a given period.

Thermal Efficiency,

$\eta$ th $=\mathrm{mc}_{\mathrm{p}}\left(\mathrm{T}_{\mathrm{f}}-\mathrm{T}_{\mathrm{i}}\right) /(\mathrm{GA})$ 
The sum of thermal and electrical efficiency is known as overall efficiency and is commonly used to assess the overall performance.

Overall Efficiency, $\eta_{\mathrm{o}}=\eta_{\mathrm{th}}+\eta_{\mathrm{e}}$

Considered electrical energy as a high grade form of energy gain, the energy saving efficiency $\eta_{\mathrm{f}}$ is also used [1]: it is defined as:

Energy saving efficiency,

$\eta_{\mathrm{f}}=\left(\eta_{\mathrm{e}} / \eta_{\text {power }}\right)+\eta_{\mathrm{th}}$

Where $\eta_{\text {power }}$ is the electric power generation efficiency of the conventional power plants; its value can be taken as $38 \%$.

\subsubsection{Energy and Exergy Analysis}

According to first law of thermodynamics,

$E_{\text {in }}=E_{\text {out }}$

General equation for the exergy balance:

$E X_{\text {in }}-E_{\text {out }}=E_{\text {loss }}$

For the steady-state flow process during a finite time interval, the overall exergy balance of the solar PV can be written as follows [2].

Exergy Input $=($ Exergy Output + Exergy Loss + Irreversibility)

The energy conversion efficiency of the solar PV ( $\left.\eta_{\text {energy }}\right)$ is calculated from the following equation: [3-4]. The currentvoltage characteristics of the electric circuit of solar cell can be described by the following simplified equation

$I=I_{1}-I_{0} \times \exp ^{\left[\frac{q \times\left(V-I R_{s}\right)}{A \times K \times T}\right]}$

The electric power output of $\mathrm{PV}$ is:

$\mathrm{P}_{\mathrm{el}}=\mathrm{I} \times \mathrm{V}$

The maximum power output is given by:

$\mathrm{P}_{\max }=\mathrm{V}_{\mathrm{OC}} \times \mathrm{I}_{\mathrm{SC}} \times \mathrm{FF}$

$\mathrm{P}_{\text {max }}=\mathrm{V}_{\mathrm{mp}} \times \mathrm{I}_{\mathrm{mp}}$

A dynamic thermal model proposed by Duffie and Beekman, included a lump overall loss coefficient UL for a unit area [5]. Exergy efficiency of the photovoltaic module is also defined as the ratio of total output exergy to total input exergy $[2,6,7]$. An exergy efficiency of the solar PV can be defined as the ratio of the exergy gained by the solar PV (exergy output) to the exergy of the solar radiation (exergy input) [8].

$\eta_{\text {ex }}=\left(E_{\mathrm{x} \text { output }}\right) /\left(\mathrm{E}_{\mathrm{x} \text { input }}\right)$
Electrical Exergy in the output electrical power of PV module [4]

$\mathrm{E}_{\mathrm{x}}$ electrical $=\mathrm{V}_{\mathrm{oc}} \times \mathrm{I}_{\mathrm{sc}} \times \mathrm{FF}$

Table 2.4: Input parameter used for analysis

\begin{tabular}{|l|l|}
\hline Input parameter & Value \\
\hline $\begin{array}{l}\text { Nominal operating cell } \\
\text { temperature (NOCT) }\end{array}$ & $41^{\circ} \mathrm{C}$ \\
\hline $\begin{array}{l}\text { Stefan Boltzmann constant } \\
(\sigma)\end{array}$ & $5.67 \times 10^{-8} \mathrm{~W} / \mathrm{m}^{2}-\mathrm{K}$ \\
\hline Emissivity of the panel $(\varepsilon)$ & 0.9 \\
\hline Sun temperature & $5800 \mathrm{~K}$ \\
\hline
\end{tabular}

\section{RESULTS AND DISCUSSION:}

The maximum global radiation reaches to $850 \mathrm{~W} / \mathrm{m}^{2}$ and maximum temperature of $44.7{ }^{0} \mathrm{C}$. Figure 3.1 shows the variation of global radiation and ambient temperature with time for PV. The maximum global radiation reaches to 990 $\mathrm{W} / \mathrm{m}^{2}$. Figure 3.2 shows the variation of front and back temperature of panel of $\mathrm{PV}$ and $\mathrm{PV} / \mathrm{T}$. Back temperature of $\mathrm{PV} / \mathrm{T}$ is lower than PV because of heat transfer from panel to flowing water. The back side temperature of $\mathrm{PV}$ panel reaches upto $73{ }^{0} \mathrm{C}$ whereas back side temperature of $\mathrm{PV} / \mathrm{T}$ reaches upto $65{ }^{\circ} \mathrm{C}$. Figure 3.3 shows the difference of inlet and outlet temperature of water. The inlet water temperature is kept below the ambient temperature for higher heat transfer rate and better efficiency. The temperature of outlet water exceeding $47.5{ }^{0} \mathrm{C}$ and maximum inlet temperature reaches upto $35^{\circ} \mathrm{C}$. Figure 3.4 shows the variation of electrical, thermal and overall efficiency with time for PV/T. the electrical efficiency is around 6-7\% and maximum of $9.7 \%$, thermal efficiency exceeding $67 \%$ and overall efficiency exceeds $69 \%$. Figure 4.18 shows the variation in electrical efficiency of PV/T and PV. The average electrical efficiency of $\mathrm{PV} / \mathrm{T}$ is $6.39 \%$ for the day and that for $\mathrm{PV}$ is $7.50 \%$. Exergy efficiency is the ratio of exergy out to exergy in. The exergy efficiency is exceeding $13 \%$ for the mass flow rate of $0.0025 \mathrm{~kg} / \mathrm{sec}$. The maximum exergy input is about $300 \mathrm{~W} / \mathrm{m}^{2}$. Exergy out is the addition of electrical exergy and thermal exergy which is reaches up to 30.8 $\mathrm{W} / \mathrm{m}^{2}$.

Table 3.1: Test Result of PV and Partially Covered PV/T system

\begin{tabular}{|l|l|l|l|l|l|l|l|l|}
\hline Time & $\begin{array}{l}\text { Global } \\
\text { Radiation } \\
\text { (PV/T) }\end{array}$ & $\begin{array}{l}\text { Global } \\
\text { Radiation } \\
\text { (PV) }\end{array}$ & $\begin{array}{l}\text { Thermal } \\
\text { Efficiency of } \\
\text { PV/T }\end{array}$ & $\begin{array}{l}\text { Electrical } \\
\text { Efficiency of } \\
\text { PV/T }\end{array}$ & $\begin{array}{l}\text { Overall } \\
\text { Efficiency of } \\
\text { PV/T }\end{array}$ & $\begin{array}{l}\text { Electrical } \\
\text { Efficiency of } \\
\text { PV system }\end{array}$ & $\begin{array}{l}\text { Exergy } \\
\text { Efficiency }\end{array}$ & $\begin{array}{l}\text { Energy Saving } \\
\text { Efficiency }\end{array}$ \\
\hline $10: 00$ & 640 & 767 & 46.509 & 9.765 & 56.275 & 8.789 & 13.310 & 46.766 \\
\hline $11: 00$ & 690 & 888 & 51.198 & 8.277 & 59.476 & 8.352 & 12.156 & 51.416 \\
\hline $12: 00$ & 707 & 918 & 53.206 & 7.181 & 60.387 & 8.176 & 12.341 & 53.395 \\
\hline $13: 00$ & 850 & 990 & 48.873 & 6.758 & 55.631 & 6.578 & 10.130 & 49.050 \\
\hline $14: 00$ & 770 & 826 & 47.153 & 6.041 & 53.195 & 8.107 & 10.603 & 47.312 \\
\hline $15: 00$ & 542 & 666 & 39.228 & 6.755 & 45.983 & 7.595 & 9.948 & 39.405 \\
\hline $16: 00$ & 250 & 375 & 47.102 & 4.067 & 51.170 & 9.466 & 4.588 & 47.209 \\
\hline $17: 00$ & 150 & 210 & 67.601 & 2.373 & 69.865 & 2.946 & 2.820 & 67.660 \\
\hline
\end{tabular}




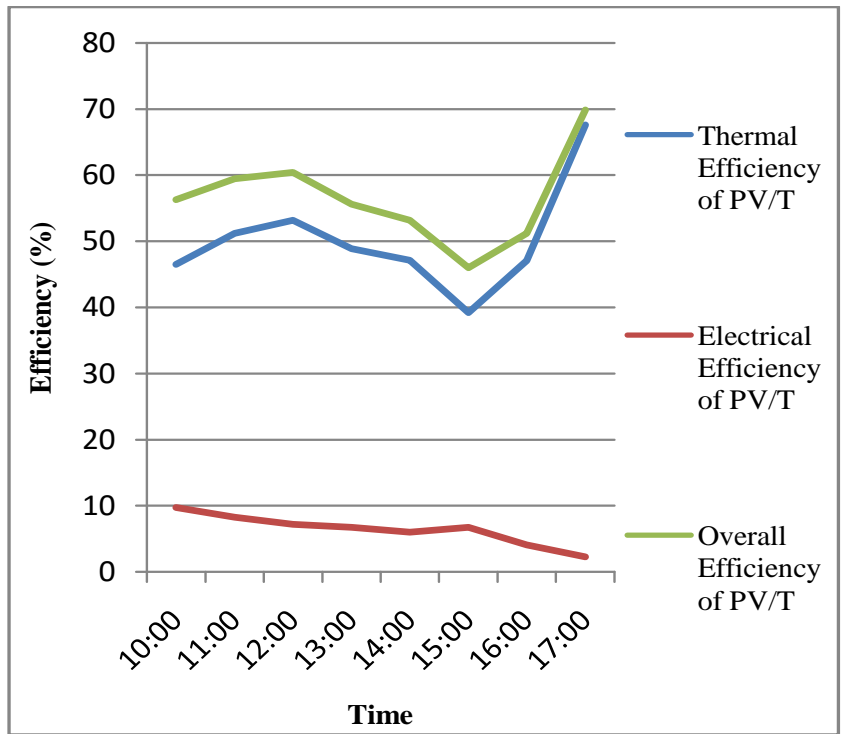

Figure 3.1: Variation of Electrical, Thermal and Overall Efficiency of PV/T with Glass Cover

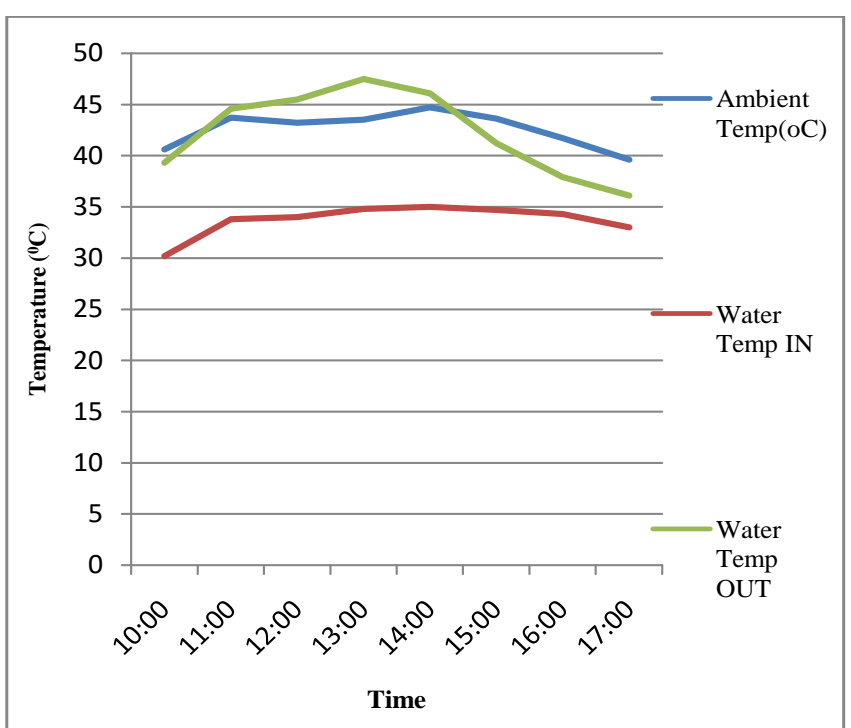

Figure 3.2: Variation of Inlet and Outlet Water Temperature for PV/T with Glass Cover

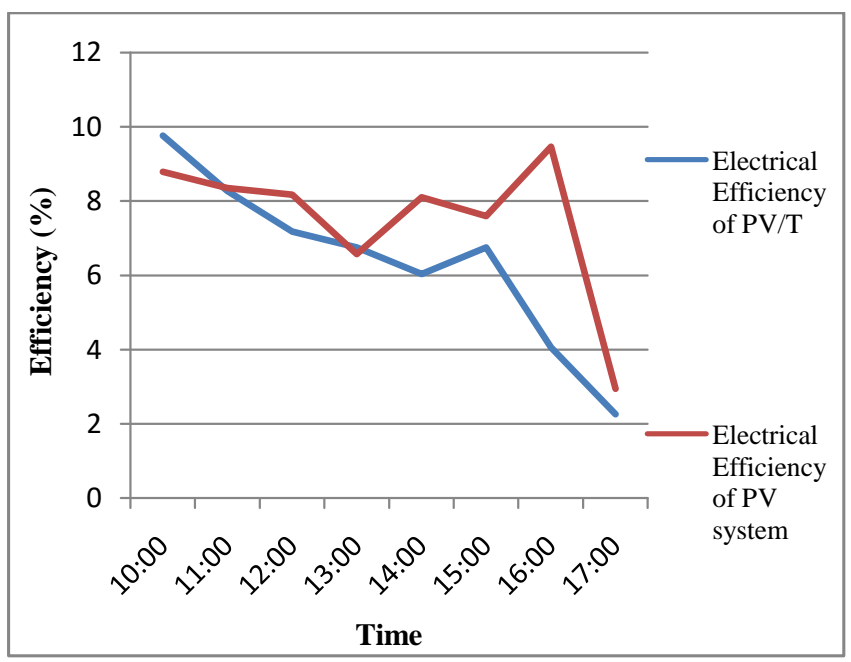

Figure 3.3: Variation of Electrical Efficiency of PV and $\mathrm{PV} / \mathrm{T}$ with Glass Cover

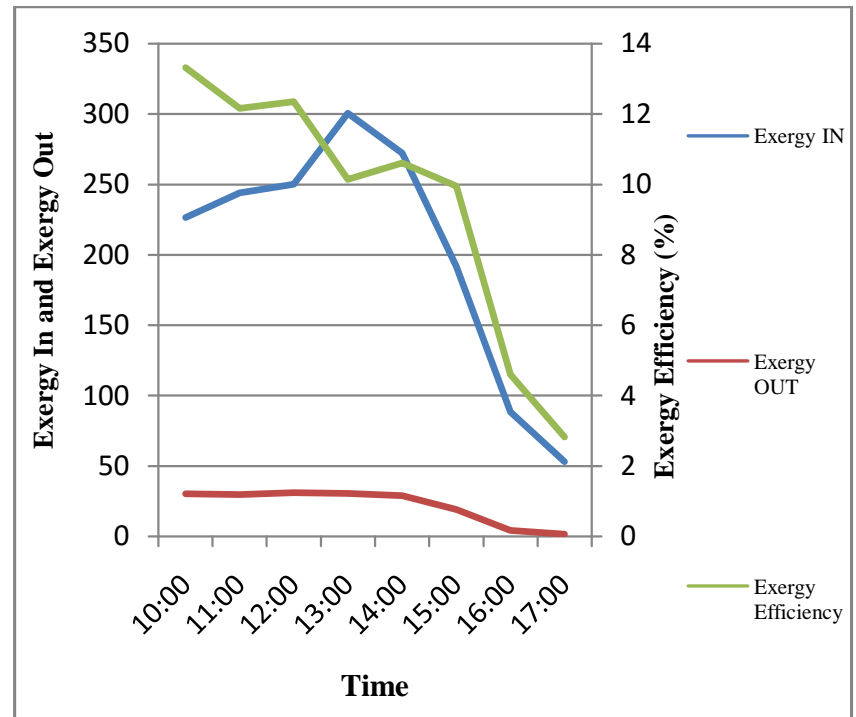

Figure 3.4: Variation of Exergy IN, Exergy OUT and Exergy Efficiency of PV/T with Glass Cover

Table 3.2: Comparison of various efficiencies of $\mathrm{PV} / \mathrm{T}$ and

\begin{tabular}{|c|c|c|c|c|c|c|c|}
\hline \\
\hline \multirow[b]{2}{*}{$\begin{array}{l}\text { S. } \\
\text { No. }\end{array}$} & \multicolumn{6}{|c|}{ Partially Covered Solar PV/T Hybrid System } & \multirow{2}{*}{$\begin{array}{l}\text { Solar } \\
\text { PV }\end{array}$} \\
\hline & 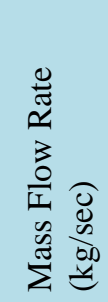 & 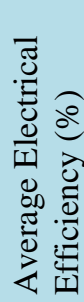 & 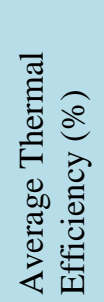 & 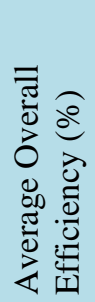 & 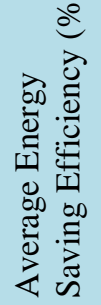 & 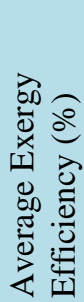 & \\
\hline 1 & 0.0025 & 6.39 & 50.11 & 56.49 & 50.27 & 9.48 & 7.50 \\
\hline
\end{tabular}

\section{CONCLUSION}

This article has presented performance evaluation of the partially covered photovoltaic thermal water collector. A partially covered solar PVT system was successfully designed and a preliminary study of this technology was carried out in a university building of MANIT, Bhopal. The surface temperature of solar PV panel is directly proportional to intensity of solar radiation. With increase in solar irradiance electrical efficiency increases but surface temperature of solar panel also increases which can affect the electrical performance of the PV system. With the combination of solar PV and solar thermal system as PVT system, the energy yield per unit area, can be improved. By using the PVT technique partially covered with glass, it was concluded from the experimental result that with the mass flow rate of $0.0025 \mathrm{~kg} / \mathrm{sec}$, the daily average electrical efficiency was about $6.39 \%$, the characteristic daily thermal efficiency exceeded $67 \%$, the characteristic average overall efficiency was above $56.49 \%$ and the characteristic daily energy saving was up to $67.66 \%$. The exergy efficiency was 
exceeds $13 \%$. The effect glass cover reduces the heat loses but it also increases the reflective losses which can be seen by comparing electrical efficiency of PV and PVT system. The high efficiency of the combined system can shorten the payback period of the entire system. The cost of adding the collector to the PV module is not very significant compared to the price of PV module itself. Therefore, the PV/T system is worth developing in the industry.

\section{NOMENCLATURE}

$\begin{array}{lll}\mathrm{n}_{\mathrm{f}} & \text { Energy Saving Efficiency } & \% \\ \mathrm{n}_{\mathrm{th}} & \text { Thermal Efficiency } & \% \\ \mathrm{n}_{\mathrm{e}} & \text { Electrical Efficiency } & \% \\ \mathrm{n}_{\mathrm{o}} & \text { Overall Efficiency } & \% \\ \mathrm{~V}_{\mathrm{oc}} & \text { Open circuit voltage } & \mathrm{V} \\ \mathrm{V} & \text { Voltage } & \mathrm{V} \\ \mathrm{V}_{\mathrm{mp}} & \text { Voltage at maximum power } & \mathrm{V} \\ & \text { point } & \\ \mathrm{I}_{\mathrm{mp}} & \text { Current at maximum power } & \mathrm{A} \\ & \text { point } & \\ \mathrm{I}_{\mathrm{sc}} & \text { Short circuit current } & \mathrm{A} \\ \mathrm{I} & \text { Current } & \mathrm{A} \\ \mathrm{FF} & \text { Fill factor } & \mathrm{No} \mathrm{units} \\ \mathrm{m} & \text { Mass flow rate } & \mathrm{Kg} / \mathrm{sec} \\ \mathrm{A} & \text { Surface area of the module } & \mathrm{m} \\ \mathrm{G} & \text { Global irradiance } & \mathrm{W} / \mathrm{m}^{2} \\ \mathrm{~K} & \text { Boltzmann constant } & \mathrm{J} / \mathrm{K} \\ \mathrm{P}_{\mathrm{el}} & \text { Electrical power } & \mathrm{W} \\ \mathrm{P}_{\mathrm{max}} & \text { Maximum power } & \mathrm{W} \\ \mathrm{T} & \text { Temperature } & \mathrm{K} \\ \mathrm{T}_{\mathrm{a}} & \text { Ambient temperature } & \mathrm{K} \\ \mathrm{T}_{\mathrm{m}} & \text { Module temperature } & \mathrm{K} \\ \mathrm{NOCT} & \text { Nominal operating } & { }^{\circ} \mathrm{C} \\ & \text { temperature } & \\ & & \end{array}$

\section{ACKNOWLEDGEMENT}

I am thankful to Dr. Appu Kuttan KK, Director, MANIT, Bhopal for giving me an opportunity to carry this work. I extend my sincere thanks to Dr. Manoj Gupta, Provost and Dean (SET), Poornima University, Jaipur for his continuous support and encouragement. I take this opportunity to express my profound gratitude and deep regards to my guide Dr. K. Sudhakar, Assistant Professor, Department of Energy, MANIT, Bhopal, for his exemplary guidance, monitoring and constant encouragement. I also express our deep thanks to all the faculty and staff members of Department of Energy, MANIT, from whom I got direct or indirect cooperation.

\section{REFERENCES}

[1] Vokas G, Christandonis N, Skittides. Hybrid photovoltaic-thermal systems for domestic heating and cooling - a theoretical approach. Sol Energy 2006;80:60715.

[2] Wong, K.F.V., 2000. Thermodynamics for engineers. University of M iami, CRC Press LLC.

[3] Sahin, A.D., I. Dincer and M .A. Rosen, 2007. Thermodynamic analysis of solar photovoltaic cell systems. Solar Energy $M$ aterials \& Solar Cells, 91: 153-159.

[4] Joshi, A.S., I. Dincer and B.V. Reddy, 2009. Thermodynamic assessment of photovoltaic systems. Solar Energy, 83(8): 1139-1149.

[5] Duffie, J. A, Beckman, W. A, 1991. Solar Engineering of Thermal Processes, 2nd ed., John Wiley and Sons, New York, USA.

[6] Bejan, A., 1998. Advanced engineering thermodynamics. John W iley \& Sons Ltd., Chichester, UK.

[7] Kotas, T.J., 1995. The exergy method of thermal plant analysis. M alabar, FL: Krieger Publish Company. [8] Petela, R., 2003. Exergy of undiluted thermal radiation. Solar Energy, 74: 469-488.

[9] Petela, R., 2008. An approach to the exergy analysis of photosynthesis. Solar Energy, 82: 3 11-328.

[10] F. Sarhaddi, S. Farahat, H. Ajam, A. Behzadmehr. 2010. Exergetic Performance Evaluation of a Solar Photovoltaic (PV) Array, Australian Journal of Basic and Applied Sciences, 4(3): 502-519.

[11] Boyle, G., 2004. Renewable energy power for a sustainable future. second ed., Oxford University Press, Oxford.

[12] Watmuff, J.H., W .W .S. Charters and D. Proctor, 1977. Solar and wind induced external coefficients for solar collectors, COMPLES 2, 56.

[13] Sukhatme, S.P., 1993. Solar energy, M cGraw-Hill, pp: 83-139.

[14] Pratish Rawat, Mary Debbarma, Saurabh Mehrotra, K.Sudhakar, Prakash Sahu, "Performance Evaluation of Solar Photovoltaic/Thermal Hybrid Water Collector" Impending Power Demand and Innovative Energy Paths, ISBN: 978-93-83083-84-8, 278-285.

[15] Pratish Rawat, Mary Debbarma, Saurabh Mehrotra, K.Sudhakar "Design, Development and Experimental Investigation Of Solar Photovoltaic/Thermal (PV/T) Water Collector System", International Journal of Science, Environment and Technology, Vol. 3, No 3, 2014, 1173 1183.

[16] Pratish Rawat, Pardeep Kumar, "Performance evaluation of Solar Photovoltaic Thermal (PV/T) System, Vol. 4, No. 8, 2015, 1466-1471.

[17] V.V. Tyagi, S.C. Kaushik, S.K. Tyagi, “Advancement in solar photovoltaic/thermal (PV/T) hybrid collector technology", Renewable and Sustainable Energy Reviews 16 (2012) 1383- 1398

[18] Wei He et. al. " Hybrid photovoltaic and thermal solar collector designed for natural circulation of water" Applied energy 83(2006) 199-210

[19] Boddaert S, Caccavelli D. Hybrid PVTh Panel optimisation using a Femlab/ Matlab/Simulink approach. Environment Identities and Mediterranean Area, ISEIMA'06. In: First international Symposium on 2006. 2006. p. 121-6.

[20] Tiwari A, Sodha MS. Performance evaluation of hybrid PV/thermal water/air heating system: a parametric study. Renewable Energy 2006; 31: 2460-74. 


\section{BIOGRAPHIES}

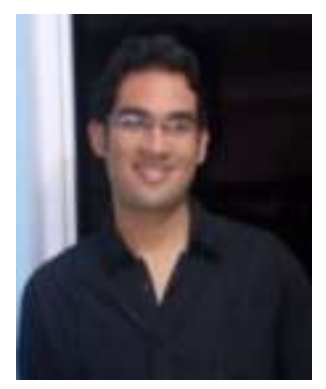

Mr. Pratish Rawat is currently working as Dy. HOD and Assistant Professor in Department of Mechanical Engineering in Poornima University, Jaipur. He obtained his B.E. in Mechanical Engineering from R.G.P.V. Bhopal and MTech in Renewable Energy from Maulana Azad National Institute of Technology (MANIT), Bhopal. His major research area includes: Energy Management and Audit, Climate Change, Hybrid System, Solar Thermal \& PV Systems, Wind Energy and Energy Conservation. He has published number of research papers in national and international journals. He also published book on solar PV/T with LAP lambert academic publishing.

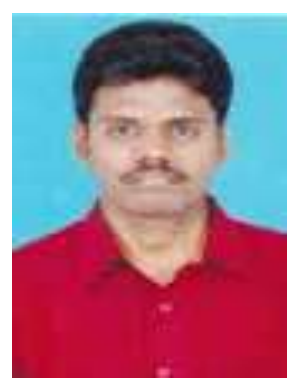

Dr. K. Sudhakar obtained his B.E in Mechanical Engineering from Government College of Engg., Salem and M.Tech in Energy Management from School of Energy And Environmental Studies, Devi Ahilya University, Indore and Ph.D from National Insitute of Technology, Tiruchirapalli.. He was awarded Senior Research Fellowship by DST and Young Scientist Award by Madhya Pradesh State Council of Science and Technology, Bhopal. His major research area includes: Climate Change, Carbon Sequestration, Hybrid System, Plant Fuel cell, Algal Biofuel, Solar Thermal \& PV Systems, Wind Energy and Energy Conservation. He has published more than 50 research papers in International Journal and Conference. He is a Certified Energy Manager \& Energy Auditor by BEE. $\mathrm{He}$ has been a keynote speaker and resource person at several International/National Conferences. He is currently working as Assistant Professor in Energy Department, Maulana Azad National Institute of Technology, Bhopal. 